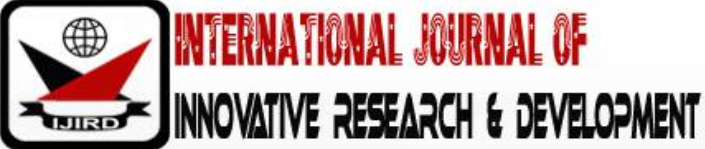

ISSN 2278 - 0211 (Online)

\section{Effectiveness of the Organization Development Interventions in Changing the Institution's Culture: A Case of Institute of Social Work and Community Development in Kenya}

Dr. Ibrahim Maticha Nyaboga

Senior Lecturer, Department of Management, Mount Kenya University, Kenya

\begin{abstract}
:
The purpose of this study was to determine the effectiveness of organization development interventions in changing the Institution's Culture in the Institute of Social work and Community Development (SWCD) in Nairobi, Kenya. It aimed at determining the degree of effectiveness of the interventions in improving the Institution's performance. This study also aimed to determine behavioral changes that can be seen after conducting the Organizational Development Interventions (ODI). This study utilized two research methods. The first was the Assessment and Evaluation which involve analysis of the Institutional problems and evaluation of the effects of the interventions. The second was descriptive research because the study involves establishing hypothesis and testing the effects of the evaluation. The questionnaire was used as an instrument for data collection. During the diagnosis the researcher administered the questionnaires to 10 respondents who were staff members of the SWCD institution to obtain the pre - intervention data. In April 2010 intervention activities were undertaken and in October, 2010 a post-intervention evaluation was done to test the effectiveness of the Organization Development interventions. The obtained data was analyzed using SPSS program and the means were computed. The Organizational Culture Assessment Instrument (OCAI) questionnaire was used. It consists of six key aspects of Organizational Culture of four questions each in which respondents were to describe their impression of the Current and Desired Organizational Culture for a total of 48 responses. It was based on Current Status and Preferred Status of Organizational Culture. The 6 areas of Organizational Culture changed from Stability and Control to Flexibility and Discretion, from Hierarchy type of culture to Clan culture. The study found that the Organizational Development Interventions is successful in redirecting the Dominant Characteristics, Organizational Leadership, Management of Employees, Organization Glue, Strategic Emphases, and Criteria of Success within the Institute of Social Work and Community Development in Nairobi - Kenya. The study recommended that regular evaluation of Institution's Culture shall be conducted in order to keep abreast of the strategic changes in the Institutional performance, as well as in the economy.
\end{abstract}

Keywords: Effects, organization development interventions, organizational culture

\section{Background}

Through decades of empirical research, scholars have established abundant links between organizational culture and organizational performance. While previously businesses were either unaware of culture's importance or believed it too difficult to manage, today they recognize that it can be used for competitive advantage. This is something that Apple Computer gets. By leveraging their culture of innovation toward product as well as internal processes, they have been able to survive despite incredible competition as well as venture into new and profitable markets. But in order to use culture strategically, a company first needs to understand its culture. And there's the rub. (Bruce M. Tharp, 2003)

Culture is a complex issue that essentially includes all of a group's shared values, attitudes, beliefs, assumptions, artifacts, and behaviors. Culture is broad encompassing all aspects of its internal and external relationships and culture is deep in that it guides individual actions even to the extent that members are not even aware they are influenced by it. Scholars tend to agree that the root of any organization's culture is grounded in a rich set of assumptions about the nature of the world and human relationships. (Bruce M. Tharp, 2003)

For example, the underlying belief that people are selfish and only out for themselves might unwittingly influence a company's attitudes and behaviors toward outside salespeople, vendors, and consultants. This is profound stuff that is largely invisible, unspoken, and unknown to an organization's members. So, is it possible to really know a company's culture? While admittedly it would be a daunting (and some might claim impossible) task to fully account for all components of a company's culture, the dominant attributes can generally be identified. In focusing on "effective organizations', research has uncovered many critical dimensions.

Acknowledging that organizational culture is an important aspect for space planners, Bruce M. Tharp provides an overview of four organizational culture types: Control (hierarchy), Compete (market), Collaborate (clan), and Create (adhocracy). This typology reflects the range of organizational characteristics across two dimensions that were found 
critical to organizational effectiveness. The spatial implications for each type are presented so that workspace planners might be able to interpret the results of an organizational culture assessment in their process of designing environments that support the way companies work and represent themselves. (Bruce M. Tharp, 2003)

John Campbell (1974) and his fellow researchers identified thirty-nine important indicators. While such a list is helpful, it is still impractical for organizations to account for so many dimensions.

Realizing this, Robert Quinn and John Rohrbaugh (1983) reviewed the results of many studies on this topic and determined that two major dimensions could account for such a broad range. Their Competing Values Framework combines these two dimensions, creating a $2 \times 2$ matrix with four clusters.

According to the research conducted by Robins (1998) said that Organizational culture is possibly the most critical factor determining an organization's capacity, effectiveness, and longevity. It also contributes significantly to the organization's brand image and brand promise. Organizational culture creates energy and momentum. The energy will permeate the organization and create a new momentum for success.

The Institution of Administrative Management (IAM) is a private institution and was established in 1998 by the shareholders who are now directors of this institution. It is situated strategically in Nairobi City. In realizing the needs of the community, the stakeholders started this institution so that the demand of the people can be realized by providing them with quality education and satisfy their demands by providing proper knowledge in community development, social work, project planning \& management and business studies.

Through the people and the researchers' own observations, the Institute of Administrative Management (IAM) lacks coordination and good relationship between the staff members, leaders and management and also the students. This has made most of the students to move out of the Institution and it has made the registration to be very low. This prompted the researcher to investigate IAM's current prevailing organizational culture, its relevance and compatibility with its Vision, Mission and Goals.

\subsection{Organizational Problems}

Through personal interview with Leaders revealed that the major challenge revolved around the institute is the ability to attract, retain and motivate employees, both lecturers and support staff. Leaders acknowledged that the institute has to compete with other institutions for it to survive. Leaders also complained of declining fees collections and rising cost of maintaining the institute. This they attributed to declining enrolment of students which resulted to low reward of employees.

The researcher's experience based on lengthy observation in the institute's culture also contributed to diagnosis process. This prompted the researcher to investigate IAM's current prevailing organizational culture, its relevance and compatibility with its Vision, Mission and Goals.

\subsection{Objectives of the Study}

To determine the effectiveness of organization development interventions in changing the Institution's Culture in the Institute of Social work and Community Development (SWCD) in Nairobi, Kenya. It aimed at determining the degree of effectiveness of the interventions in improving the performance of the Institution. This study also aimed to determine behavioral changes that can be seen after conducting the Organizational Development Interventions (ODI)

\section{Literature Review}

This research study is anchored on the theory propounded by Schein (2003) which states "The bottom line for institution is that if it does not become conscious of the culture in which it has embedded, those cultures will manage them'. Every institution will experience change, the question of how the institution attempts to deal with this change as of interest. Changing organizational culture is by no means an easy task, since it develops over a period of time and gets embedded within the very structure, systems and processes in which it develops. He concluded,

An organization's culture develops to help it cope with its environment. Organizations are confronted with many complex issues during their attempts to generate organizational achievement in its environments. He reveals that cultural analysis is especially valuable for dealing with 2 aspects of organizations that seem irrational, frustrating, and intractable.

According to Schein (2003) an MIT professor of management and author of organizational culture and leadership said that an organization's culture develops to help it cope with its environment. Organizations are confronted with many complex issues during their attempts to generate organizational achievement in its environments. He reveals that cultural analysis is especially valuable for dealing with 2 aspects of organizations that seem irrational, frustrating, and intractable.

To review the Institution's current culture which is operated and practiced, it depends entirely on people's attitudes and culture. He further said that, the customaries attitude towards its product the higher the usage and vice versa, Institutions must be interested in finding out what the prevailing attitudes towards their product(s) are, how to change unfavorable attitudes and how to maintain the mode positive ones. Drucker (1998)

\subsection{Supporting Studies}

During the conduct of this study, the researcher diagnosis to get the information concerning with the dimension of developing the Institution and the staff workers.

Part of the study of Okongo (2001) related to this study is the development of the staff members of Commercial College of Kenya. He revealed that development of an Organization depends entirely on the peoples' willingness to change. He concluded in his study that the development of Organizational Culture was an important thing in the development and 
improvement of the Institution. He argued that in order for the Institution to compete and meet the challenges in today's world, must accept to undergo changes for it to attain success.

Related to this study, is the study of Chatman and Jehn (1994) who identified seven primary characteristics that define an organization's culture: innovation, stability (maintaining the status quo versus growth), people orientation, outcome orientation, easygoingness, detail orientation, and team orientation. They concluded that, the development of Organizational Culture can develop or hinder the development of the Institution.

The management literature applicable to organizational development suggests that organizational culture is directly related to the leadership style exhibited by the primary manager of the organization or unit. It also indicates that successful leaders we those who generate effective organizations (Cameron \& Quinn, 2006).

They further proposed that the manager must implement a change process to foster cultural transformation and align personal managerial behavior with the culture change (Cameron and Quinn, 2006).

According to Warren Bennis managers are people who do things right and leaders are people who do the right thing (Bennis \& Nanus, 1995).

Cameron and Quinn (2006) strongly suggest that it takes both leadership and management to strengthen, maintain, change, or create a culture in any quadrant. They offer another elucidation of leadership theory in which paradoxical values shift regularly as they react to the organization's ever-changing culture, goals and needs. Organizations are dynamic and thus require dynamic managers. When cultures change, leadership styles must also change.

According to Quinn and Cameron's (2006) extensive research, it was found that most organizations have developed a dominant culture style. An organization rarely has only one culture type. Often, there is a mix of the four organizational cultures. They found that flexible organizations are the most effective, which sometimes leads to contradictory behavior. The 'best' organization can handle the competition within this framework well and use all four Value sets when necessary. They argued that there is no ultimate 'best' organizational culture. Only in a certain context will one type of culture serve better than another.

\section{Theoretical Framework}

The Five Phases Action Research, a descriptive analytical research that was conducted to prove the Organizational Culture and the development needs of the Institute of Administrative Management (IAM). Figure 1 below illustrates the process followed during the Interventions.

- Diagnosis - Pre-assessment using the questionnaire as an instrument in gathering the data to the 10 respondents, June, 2008.

- Action Planning - the Leaders together with the researcher plan the implementation on the Organization development Interventions and the development needs as by the vision, mission and goals, June, 2009.

- Action-taking - the organizational development intervention program, was supervised by the researcher for six months duration, starting April, 2010.

- $\quad$ Evaluation - A post test was taken on the same subjects on January, 2011.

- $\quad$ Specific Learning - the two means were used for comparing the pre - test and post - evaluation data.

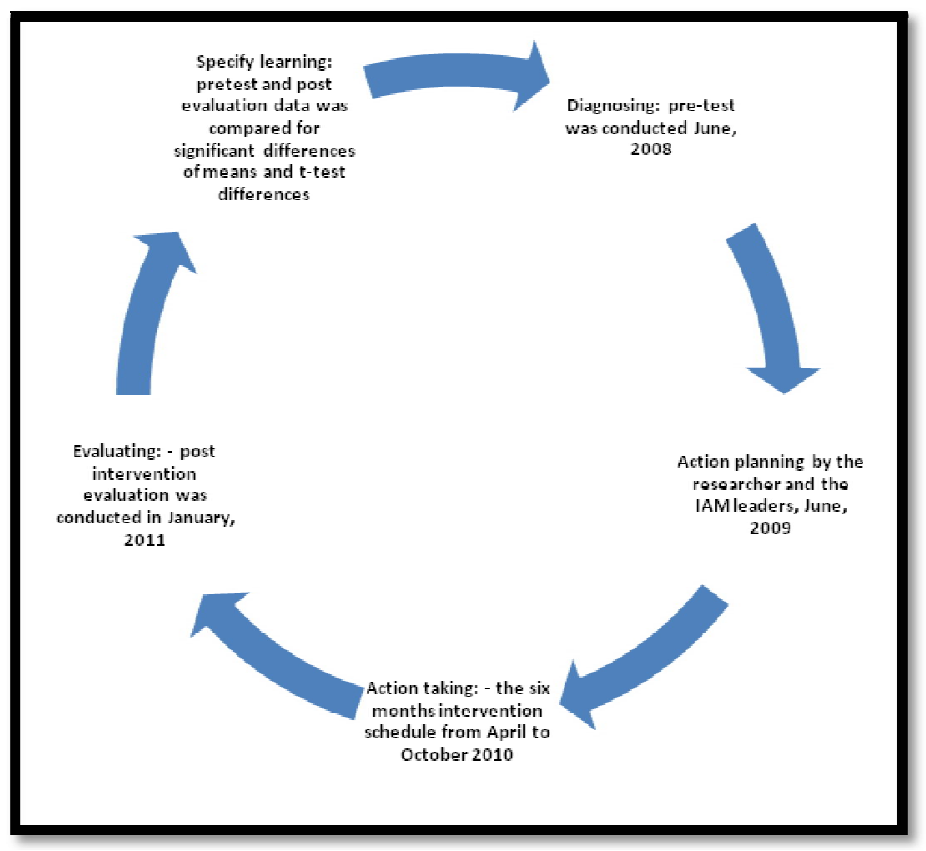

Figure 1: The Action Research Cycle by Susmans and Evereds 


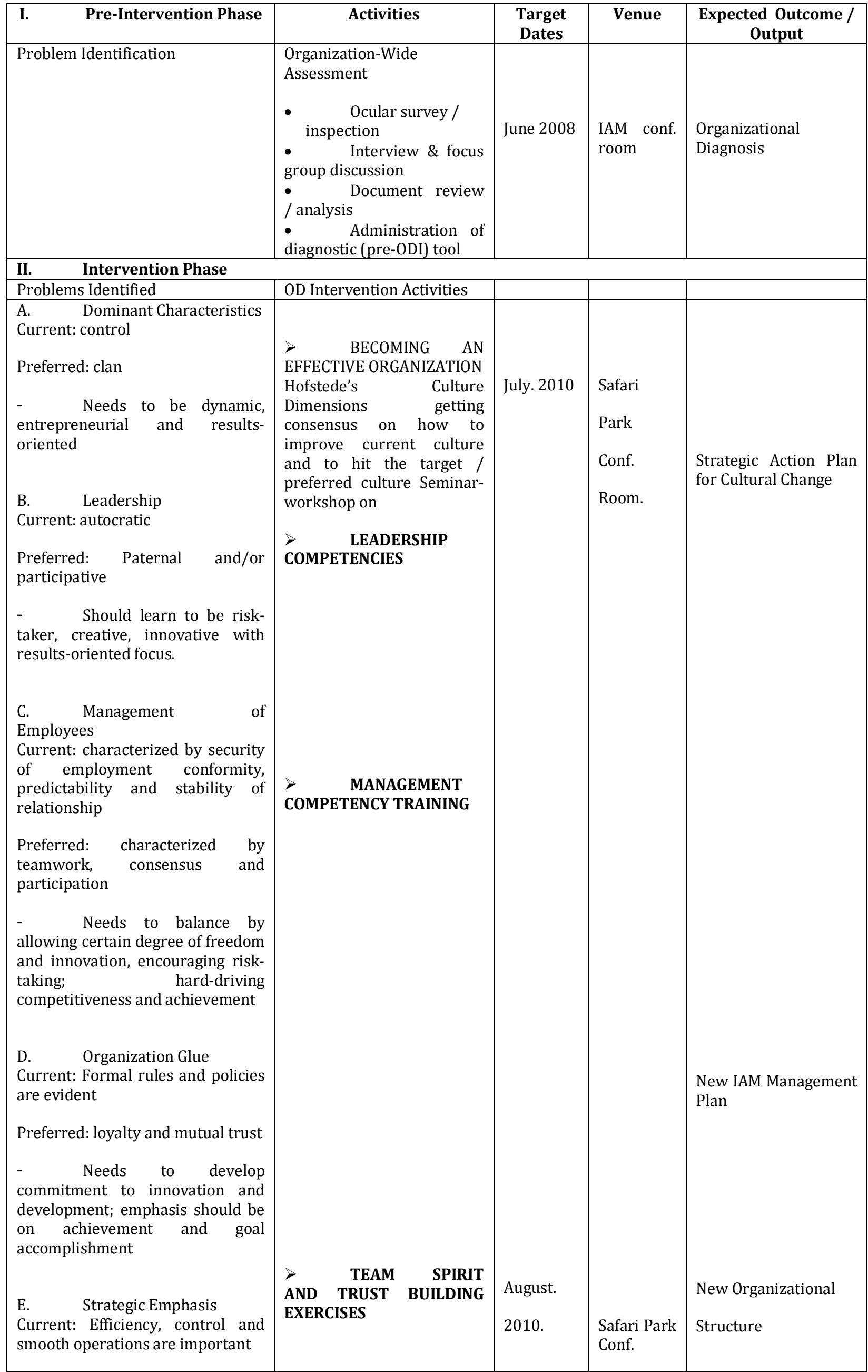




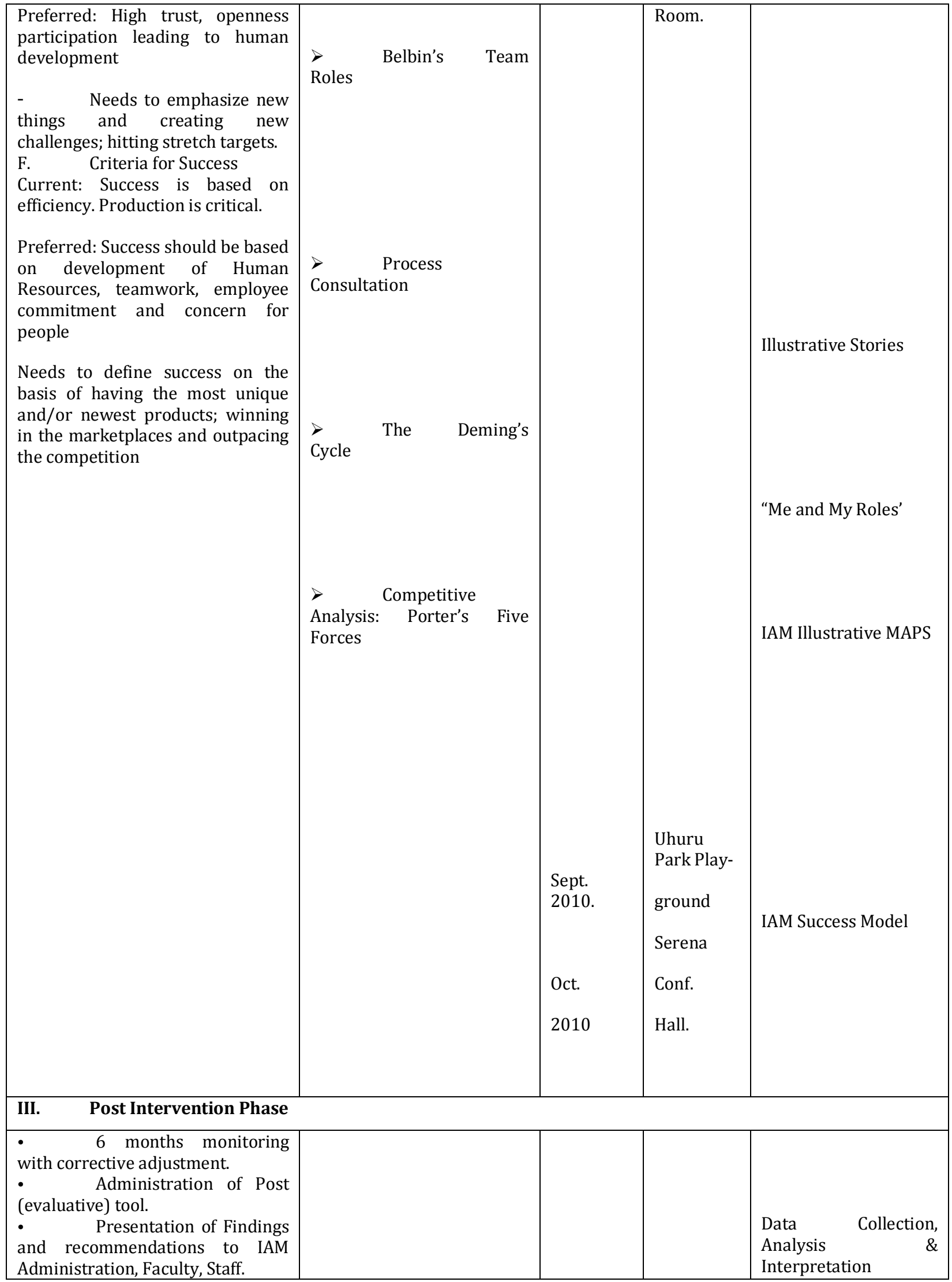

Table 1: Schedules of Intervention Activities

\subsection{Organizational Development Interventions (ODI)}

First the participants were briefed on how the activities were to be carried out. They were then subjected to brainstorming sessions in order to internalize and own up the process. The participants were motivated and encouraged to be flexible, free and creative in carrying out the activities.

On the Organizational leadership, the Institution was to train their leaders to cut corporate directives and purge the tendency to micromanage. The Institutional leadership should push the decision - making responsibilities to people. This was achieved by planning and organizing seminars and workshops on Leadership Competency Training. 
The issue of Management of employees was addressed through Mentoring, team building activities, developing human resource and through open communication. This was achieved through Management Competency Trainings. At the end of the Interventions Activities, the Institution (IAM) was able to put in place New Management Plan.

To improve Dominant characteristics, the Institution eliminated useless rules and procedures which tend to control what people do. Also, the Institution removed ease paperwork and reports which seems to hinder employee participation. Regular meetings were held to provide forum for information sharing and teambuilding. Outside seminars, workshops and training conferences was organized. Games exercise and on-going competitions was planned. This was intended to enable staff members to improve their personality, be able to interact freely, able to understand diversity, develop respect for each other and form the right attitudes for life in the dynamic world. After each session participants were allowed to assess each other's behavior and suggest areas of improvement. These helped the Institute of Administrative Management (IAM) to put in place the Strategic Action Plan for Cultural Change.

To improve organization Glue, loyalty and mutual trust and commitment was emphasized. To achieve these, Team Spirit and Trust Building Exercises were organized. Through these, commitment to innovation and development; emphasis should be on achievement and goal accomplishment Therefore, trainings, seminars, educational trips, Capacity building, were planned and ongoing trainings were organized.

To change the Strategic Emphases, the Institution emphasized on human development, openness, high trust, and employee participation. This was achieved through emphasizing and by using Beibin's Team Roles and regular meetings plus Seminars. The Institution (IAM) emphasized new things and creating new challenges, hitting stretch targets.

Finally, the criteria of success were dealt with by using Competitive analysis; Porter's Five Forces and The Deming's Cycle. These lead to IAM Success Model. Planned sessions with both staff and management, so the Institution's success can be defined on the basis of the development of human resources, teamwork, employee commitment and concern for people.

The participants were required to share their experiences and state how they could do better if given more opportunity. The participants were to carry out these activities in their work place and outside work place as a matter of improving organizational culture.

\section{Methodology}

This research utilized two research methods. The first was the Assessment and Evaluation which involve analysis of the Institutional problems and evaluation of the effects of the interventions.

The second was descriptive research because the study involves establishing hypothesis and testing the effects of the evaluation. The questionnaire was used as an instrument for data collection.

\section{Discussions and Results}

\subsection{Profiles of the Current and Preferred Statuses before and after ODI}

Table 2 - 7 below show the means obtained before and after the pre and post interventions.

\begin{tabular}{|l|c|c|c|c|}
\hline \multicolumn{1}{|c|}{ A. Dominant Characteristics Indicators } & \multicolumn{2}{c|}{ Current Status } & \multicolumn{2}{c|}{ Preferred Status } \\
\cline { 2 - 5 } & Before ODI & $\begin{array}{c}\text { After } \\
\text { ODI }\end{array}$ & $\begin{array}{c}\text { Before } \\
\text { ODI }\end{array}$ & After ODI \\
\hline $\begin{array}{l}\text { 1. The organization is a very personal place. It is } \\
\text { like an Extended family. People seem to share a lot } \\
\text { of themselves }\end{array}$ & 09.00 & 54.50 & 54.00 & 60.00 \\
\hline $\begin{array}{l}\text { 2. The organization is a very dynamic and } \\
\text { entrepreneurial place. People are willing to stick } \\
\text { their necks out and take risks }\end{array}$ & 20.00 & 19.50 & 20.00 & 16.50 \\
\hline $\begin{array}{l}\text { 3. The organization is very results-oriented. A } \\
\text { major concern is with getting the job done. People } \\
\text { are very competitive and achievement-oriented }\end{array}$ & 23.50 & 15.00 & 15.00 & 15.50 \\
\hline $\begin{array}{l}\text { 4. The organization is a very controlled and } \\
\text { structured place. Formal Procedures generally } \\
\text { govern what people do }\end{array}$ & 48.00 & 11.00 & 11.00 & 08.00 \\
\hline TOTAL (Each Column Must Equal 100) & 100 & 100 & 100 & 100 \\
\hline
\end{tabular}

Table 2: Mean scores on Dominant Characteristics for the OCAI before and after ODI

Table 2 above shows the pre and post interventions means indicating the Current and Preferred Status before and after Organization Development Interventions (ODI). For the Current Status before the ODI, (09.00) after the ODI it is (54.50). Preferred Status before the ODI the mean scores is (54.00) after the ODI it is (60.00). It revealed that, the people preferred the organization to be a very personal place, like an extended family, where people seem to share a lot for themselves.

Item number two, the Current Status before ODI was (20.00) after the ODI it is (19.50). Preferred Status before the ODI the mean score was (20.00) and after ODI it is (16.50). This revealed that the IAM staff is not willing to stick their necks out and take risks. 
Item number three, the Current Status before ODI was 23.50 after the ODI it is (15.00). Preferred Status before the ODI the mean score is 15.00 after the ODI it is (15.50). It indicated that people did not prefer competition and achievement. Their major concern is not with getting the job done.

Item number four, the Current Status before ODI was 48.00 after the ODI it moved to (11.00). Preferred Status before the ODI the mean score was 11.00 after the ODI it is (08.00). It revealed that the people did not want the organization to be controlled and structured, formal procedures should be done away with. It proved that the ODI activities was able to changed the organization's Dominant Characteristics from controlled and structured place to a very personal place, where people seem to share a lot of themselves.

\subsection{Organizational Leadership}

\begin{tabular}{|c|c|c|c|c|}
\hline \multirow[b]{2}{*}{ B. Organizational Leadership Indicators } & \multicolumn{2}{|c|}{ Current Status } & \multicolumn{2}{|c|}{ Preferred Status } \\
\hline & $\begin{array}{c}\text { Before } \\
\text { ODI }\end{array}$ & $\begin{array}{c}\text { After } \\
\text { ODI }\end{array}$ & $\begin{array}{c}\text { Before } \\
\text { ODI }\end{array}$ & After ODI \\
\hline $\begin{array}{l}\text { 1.The leadership in the organization is generally considered to exemplify } \\
\text { mentoring, facilitating, or nurturing. }\end{array}$ & 11.00 & 52.00 & 55.50 & 57.50 \\
\hline $\begin{array}{l}\text { 2. The leadership in the organization is generally considered to } \\
\text { Exemplify entrepreneurship, innovation, or risk taking. }\end{array}$ & 23.50 & 21.50 & 18.50 & 19.50 \\
\hline $\begin{array}{l}\text { 3. The leadership in the organization is generally considered to exemplify } \\
\text { a no-nonsense, aggressive, results-oriented focus. }\end{array}$ & 22.00 & 15.00 & 15.00 & 13.50 \\
\hline $\begin{array}{l}\text { 4. The leadership in the organization is generally considered to exemplify } \\
\text { coordinating, organizing, or smooth-running efficiency. }\end{array}$ & 43.50 & 11.50 & 11.00 & 09.50 \\
\hline TOTAL (Each column must equal 100) & 100 & 100 & 100 & 100 \\
\hline
\end{tabular}

Table 3: Presents the Data on Organizational Leadership

Mean Scores on Organizational Leadership for the OCAI Before and After ODI

It was revealed that the Current Status before ODI, the Leadership in the organization was not exemplifying coordinating, organizing, or smooth-running efficiency because of the percentage of the mean score was (11.00). After the ODI, the Leadership in the organization was desired to be exemplifying mentoring, facilitating, or nurturing because of the small percentage of means score of (52.00). After the ODI, the score was (52.00) and the preferred status is (57.50).

This shows that the Organizational Development Interventions activities were successful in changing the organizational leadership from the Current Status (Hierarchy type of Culture) to Preferred Status (Clan Culture). With the application of ODIA, workshops / seminars on leadership competencies, brought changes in the overall organizational leadership of IAM.

\subsection{Management of Employees}

\begin{tabular}{|l|c|c|c|c|}
\hline \multirow{2}{*}{ C. Management of Employees Indicators } & \multicolumn{2}{l|}{ Current Status } & \multicolumn{2}{l|}{ Preferred Status } \\
\cline { 2 - 5 } & $\begin{array}{c}\text { Before } \\
\text { ODI }\end{array}$ & $\begin{array}{c}\text { After } \\
\text { ODI }\end{array}$ & $\begin{array}{c}\text { Before } \\
\text { ODI }\end{array}$ & After ODI \\
\hline $\begin{array}{l}\text { 1. The management style of the organization isCharacterized } \\
\text { by teamwork, consensus, and participation. }\end{array}$ & 11.50 & 53.50 & 50.00 & 59.00 \\
\hline $\begin{array}{l}\text { 2. The management style of the organization is characterized } \\
\text { by individual risk taking innovation, freedom, and } \\
\text { uniqueness. }\end{array}$ & 21.50 & 21.00 & 21.00 & 17.50 \\
\hline $\begin{array}{l}\text { 3. The management style of the organization is characterized } \\
\text { by hard-driving competitiveness high-demand, and } \\
\text { achievement. }\end{array}$ & & 15.00 & 15.00 & 14.00 \\
\hline $\begin{array}{l}\text { 4. The management style of the organization is characterized } \\
\text { by security of employment, conformity, predictability, and } \\
\text { stability in relationships. }\end{array}$ & 42.00 & 10.00 & 14.00 & 09.50 \\
\hline Total (Each column must equal 100) & 100. & 100 & 100. & 100. \\
\hline
\end{tabular}

Table 4: Presents the Data on Management of Employees

Mean Scores on Management of Employees for the OCAI before and After ODI

The Current Status of the management style before ODI it was (11.50) and the preferred Status before ODI was (50.00). It revealed that the Current Status before the ODI the Management style of the organization was not characterized by teamwork, consensus, and participation. After ODI the current status was (53.50) and the preferred status was (59.00).

Before ODI the management style was rated (21.50) and preferred was (21.00). After ODI the current status was changed to (21.00) and the preferred status was (17.50). This means that people preferred the organization not to be characterized by individual risk -taking, innovation, freedom and uniqueness.

Before ODI the Management style was (25.00) and preferred was (15.00). After ODI the current status was (15.50) and the preferred status was (14.00). This means that the members of the organization did not want the organization to be characterized by hard -driving competitiveness, high-demand, and achievement. 
Before ODI the Management style was characterized by security of employment, conformity, predictability, and stability in relationship as indicated by a score of (42.00) for the current status. The preferred status before ODI was (14.00). After ODI the rating it was (09.50). This means that the people did not favor control and stability.

To have a participative organization there should be cutting of corporate directives and purge the tendency to micromanager while pushing the decision - making responsibilities down to the front lines. (Cameron and Quinn, 2006).

\subsection{Organization Glue}

\begin{tabular}{|c|c|c|c|c|}
\hline \multirow[b]{2}{*}{ D. Organization Glue Indicators } & \multicolumn{2}{|c|}{ Current Status } & \multicolumn{2}{|c|}{ Preferred Status } \\
\hline & $\begin{array}{c}\text { Before } \\
\text { ODI }\end{array}$ & $\begin{array}{c}\text { After } \\
\text { ODI }\end{array}$ & Before ODI & After ODI \\
\hline $\begin{array}{l}\text { 1. The glue that holds the organization together is } \\
\text { loyaltyand mutual trust. Commitment to this } \\
\text { organization runs high. }\end{array}$ & 10.50 & 54.50 & 55.00 & 60.00 \\
\hline $\begin{array}{l}\text { 2. The glue that holds the organization together is } \\
\text { commitment to innovation and development. There is } \\
\text { an emphasis on being on the cutting edge. }\end{array}$ & 23.50 & 19.50 & 16.00 & 17.00 \\
\hline $\begin{array}{l}\text { 3. The glue that holds the organization together is the } \\
\text { Emphasis on achievement and goal accomplishment. }\end{array}$ & 21.50 & 15.00 & 16.00 & 14.00 \\
\hline $\begin{array}{l}\text { 4. The glue that holds the organization together is } \\
\text { formal rules and policies. Maintaining a smooth- } \\
\text { running organization is important. }\end{array}$ & 44.50 & 11.00 & 13.00 & 09.00 \\
\hline Total (Each column must equal 100) & 100 & 100 & 100 & 100 \\
\hline
\end{tabular}

Table 5: Shows the data on the Organization Glue

Mean scores on Organization Glue for the OCAI before and after ODI

Table 5 shows the changes in the organizational glue which holds the institution together before the OD Intervention activities. The rating was (10.50) and preferred was (55.00) for the preferred status.

After the ODI the current status was (54.50) and later increased to (60.00). This means that the people consider loyalty and mutual trust and commitment to the organization.

Before ODI the glue that holds the organization together was (23.50).and later was rated (16.00). After ODI the preferred status was (16.00) and later was given (17.00). This means that the people of the organization did not prefer commitment to innovations and development.

Before ODI the emphasis was on achievement and goal accomplishment with the rating of (21.50). The preferred status was (16.00). After ODI the current status was (15.00) and the preferred status was (14.00). This means that the emphasis of the organization was not on achievement and goal accomplishment.

Before ODI the rating was (44.50) for current status then changed to (13.00). After ODI the current status was (11.00) and the preferred is (09.00). This means that the intervention activities make people prefer mutual trust and loyalty plus commitment. There was team spirit and trust among employees and management.

\subsection{Strategic Emphases}

\begin{tabular}{|l|c|c|c|c|}
\hline \multirow{2}{*}{ E. Strategic Emphases Indicators } & \multicolumn{2}{|c|}{ Current Status } & \multicolumn{2}{c|}{ Preferred Status } \\
\cline { 2 - 5 } & $\begin{array}{c}\text { Before } \\
\text { ODI }\end{array}$ & $\begin{array}{c}\text { After } \\
\text { ODI }\end{array}$ & $\begin{array}{c}\text { Before } \\
\text { ODI }\end{array}$ & After ODI \\
\hline $\begin{array}{l}\text { 1. The organization emphasizes human development. } \\
\text { High trust, openness, and participation persist. }\end{array}$ & 10.00 & 49.50 & 59.50 & 59.00 \\
\hline $\begin{array}{l}\text { 2. The organization emphasizes acquiring new resources } \\
\text { and creating new challenges. Trying new things and } \\
\text { prospecting for opportunities are valued. }\end{array}$ & 24.50 & 20.00 & 16.50 & 18.00 \\
\hline $\begin{array}{l}\text { 3.The organization emphasizes competitive actions and } \\
\text { achievement. Hitting stretch targets and winning in the } \\
\text { market place are dominant. }\end{array}$ & 22.00 & 17.00 & 11.50 & 13.50 \\
\hline $\begin{array}{l}\text { 4. The organization emphasizes permanence and stability. } \\
\text { Efficiency, control, and smooth operations areimportant. }\end{array}$ & 43.50 & 13.50 & 12.50 & 09.50 \\
\hline TOTAL (Each column must equal 100) & 100 & 100 & 100 & 100 \\
\hline
\end{tabular}

Table 6: Presents the Data on Strategic Emphases

Mean Scores on Strategic Emphases for the OCAI Before and after ODI

The respondents indicated that the Current Status before ODI was (10.00) and the preferred status was (59.50). After the ODI the current status was (49.50) and later became (59.00). This means that the intervention activities indicated human development, high-trust, openness and participation.

On the acquiring new resources and creating new challenges, the current status before ODI was (24.50) and the preferred status was (16.50). After the ODI the current status was (20.00) and the preferred status was (18.00). This means that the respondents were not willing to try new things. 
On the organization's emphasis on competitive actions and achievement, the current rating is (22.00) and the preferred rating is (11.50). After ODI the rating was changed to (11.50) and preferred rating is (13.50). The ODIA resulted in the emphasis on hitting targets and winning in the market place.

On the emphasis on permanence and stability before ODI the current rating is (43.50) and the preferred rating is (12.50). After the ODI preferred rating is (13.50) and later changed to (09.50). This means that the emphasis of the organization is not on permanence and stability, efficiency and control.

"The bottom line for institution is that if it does not become conscious of the culture in which it has embedded, those cultures will manage them'. (Schein, 2003).

\subsection{Criteria of Success}

\begin{tabular}{|l|c|c|c|c|}
\hline \multicolumn{2}{|l|}{ F. Criteria of Success Indicators } & \multicolumn{2}{l|}{ Current Status } & \multicolumn{2}{l|}{ Preferred Status } \\
\cline { 2 - 5 } & $\begin{array}{c}\text { Before } \\
\text { ODI }\end{array}$ & $\begin{array}{c}\text { After } \\
\text { ODI }\end{array}$ & $\begin{array}{c}\text { Before } \\
\text { ODI }\end{array}$ & After ODI \\
\hline $\begin{array}{l}\text { 1. The organization defines success on the basis of the } \\
\text { development of Human resources teamwork, } \\
\text { employee commitment, and concern for people. }\end{array}$ & 12.50 & 52.50 & 57.00 & 58.00 \\
\hline $\begin{array}{l}\text { 2. The organization defines success on the basis of } \\
\text { having the most unique or newest products. It is a } \\
\text { product leader and innovator. }\end{array}$ & 22.50 & 21.50 & 15.50 & 18.00 \\
\hline $\begin{array}{l}\text { 3. The organization defines success on the basis of } \\
\text { winning in the marketplace and outpacing the } \\
\text { competition. Competitive market leadership is the key. }\end{array}$ & 20.50 & 15.50 & 15.00 & \\
\hline $\begin{array}{l}\text { 4. The organization defines success on the basis of } \\
\text { efficiency. Dependable delivery, smooth scheduling, } \\
\text { and low-cost Production is critical. }\end{array}$ & 44.50 & 10.50 & 12.50 & \\
\hline TOTAL (Each column must equal 100) & & & & \\
\hline
\end{tabular}

Table 7: Shows the Data on Criteria of Success

Mean Scores on Criteria of Success for the OCAI Before And After ODI

From Table 7 above shows the Current Status before the Organizational Development Interventions (ODI) was 12.50 and the preferred status is 57.50. After ODI the rating was changed to 52.50 and the preferred status is 58.00 . This means that the respondents define success on human development, teamwork, employee commitment, and concern for people.

Before ODI the current status was (22.50) and the preferred status was (15.50). After the ODI the preferred status was (21.50) and later was changed to (18.00). The institution defines success on the basis at first. After the ODI the organization change its criteria of success from competitive market leadership to human resources, employee commitment and concern for people.

On the basis of winning success in the market place the current status is (20.50) and the preferred is (15.00). After the ODI the preferred status is (15.50) and later it was changed to (15.00). This means that the organization members do not prefer competitive market leadership.

The organization defines success on the basis for efficiency. Before the ODI the current rating was (44.50) and then become (12.50). After the ODI the preferred status is (10.50) and later changed to (09.00). The ODI activities changed the criteria of success to human development, teamwork, employee commitment, and concern for people.

\subsection{Culture Profile}

\begin{tabular}{|l|c|c|c|c|}
\hline \multirow{2}{*}{ Culture } & \multicolumn{2}{|c|}{ Current Status } & \multicolumn{2}{c|}{ Preferred Status } \\
\cline { 2 - 5 } & Before ODI & After ODI & Before ODI & After ODI \\
\hline 1. Clan & 10.83 & 52.75 & 55.17 & 58.90 \\
\hline 2. Adhocracy & 22.50 & 20.50 & 17.92 & 17.75 \\
\hline 3. Market & 22.25 & 15.50 & 14.58 & 14.25 \\
\hline 4. Hierarchy & 44.42 & 11.25 & 12.33 & 09.10 \\
\hline \multicolumn{1}{|c|}{ Total } & 100 & 100 & 100 & 100 \\
\hline
\end{tabular}

Table 8: Shows the Culture Profile Before and After ODI

The Culture Profile Before and after ODI

Table 8 shows the Current Culture Status and preferred status before and after the ODI. It was evident from the table above that, the Current Status before ODI for the Clan Culture was (10.83) which was the lowest mean score of the four and the highest mean score was in Hierarchy type of Culture with (44.42) This implies that, the Institution was dominated by Hierarchy type of Culture. After the implementation of ODIA, the highest mean score was on Clan Culture 
with (52.75), and the lowest was on Hierarchy type of Culture with (11.25). The Preferred Status before the ODI revealed that the staff of the Institute of Administrative Management IAM prefers Clan type of Culture with a mean score of (58.90) against (09.10) of Hierarchy type of Culture. This revealed that the Organization Development Interventions Activities (ODIA) were successful in redirecting the Clan Culture, Adhocracy type of Culture, Market type of Culture, and Hierarchy Culture within the Institute of Administrative Management in Kenya.

This confirms the theory propounded by Drucker which states, "Institutions that learn on how to successfully deal with Cultural change and avoid long frustrating transitions will sharpen their comparative advantage'. (Drucker, 1998).

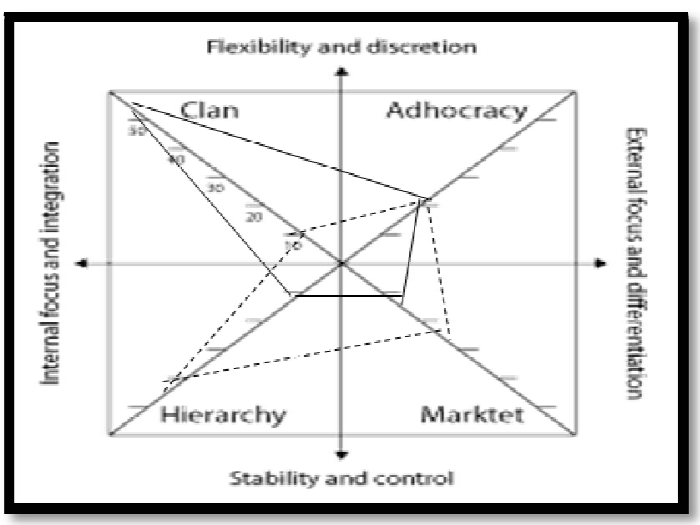

Figure 2: Current Status

-...- - Shows the Current Culture Status before the ODI

- Shows the Current Culture Status after the ODI

Figure 2 above represents the Current Culture before and after Organizational Development Interventions Activities (ODIA). It was revealed that before the ODI the Organization was characterized by Hierarchy type of culture (44.42). After the implementation of the ODI the Institution is now characterized by Clan type of culture (52.75)

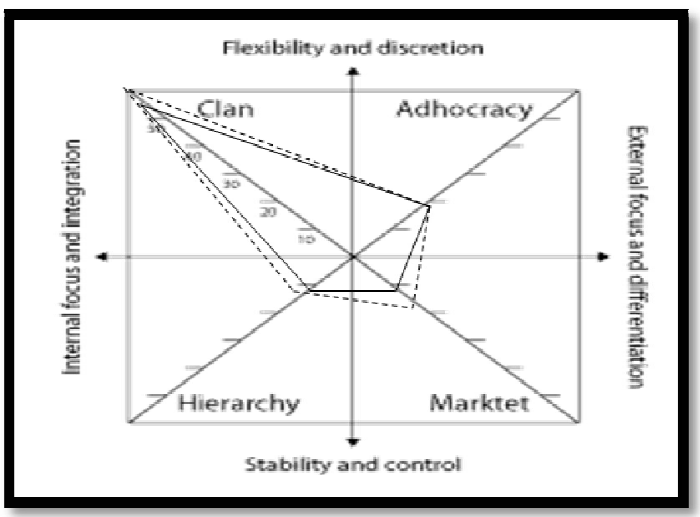

Figure 3: Preferred Status

Shows the Preferred Culture Status before the ODI

Shows the Preferred Culture Status after the ODI

Figure 3 presents the Preferred Culture Status which shows that there is a slight difference between the preferred culture before the ODI and the preferred culture after the ODI. The Clan culture shows the difference before ODI and after ODI where the mean score changed from 55.17 to 58.90. The mean score of Hierarchy Culture moved down from 12.33 to 09.10 after the Organization Development Interventions (ODI).

\section{Conclusions}

The Organization Development Interventions (ODI) changed the Institutional Culture of the Institute of Social Work and Community Development (SWCD) from the Current (Hierarchy) type to the preferred (Clan) type of culture. The Organizational Development Interventions is successful in redirecting the Dominant Characteristics, Organizational Leadership, Management of Employees, Organization Glue, Strategic Emphases, and Criteria of Success within the Institute of Administrative Management (IAM) in Kenya. The shift from Hierarchy to Clan Culture is a result of application of appropriate (right fit) Organizational Development Interventions Activities (ODIA).

Therefore, the Organizational Development Interventions Activities (ODIA) gave way to achieving the Preferred Status of Organizational Culture that is Clan type of Culture in IAM.

\section{Recommendations}

Resulting from the findings and conclusion of this study, the following recommendations are critical:

- In regard to Dominant Characteristics, there is need to continuously put in place Strategic Action Plan for Cultural Assessment and Change. It should be a continuous exercise. These can be achieved by getting consensus with the 
people concern on how to improve Current Culture and to hit the target / Preferred Culture, so as to become an effective Organization. There is also need to use Hofstede's Five Dimensions of Culture as a framework for Assessing Organizational Culture if an Organization wants to survive.

- In terms of Organizational Leadership, there should be consistent planning for Seminars / workshops on Leadership Competencies. These will make the Leaders or executives to become like paternal or participative. They should learn to be risk - takers, creative with results - oriented focus.

- In regard to Management of Employees, it is recommended that, there should be regular Management Competency Training. New IAM Management Plan should be formed. There is need to balance by allowing certain degree of freedom and innovation, encouraging risk - taking, hard - driving, competitiveness and achievement. Teamwork, Consensus and Participation is recommended which can be achieved through (MCT).

- It is recommended that Team Spirit and Trust Building Exercises should be arranged for the Organization Glue. These will increase loyalty and mutual trust among the members of the Institution. In order to reinforce Strategic Emphases, the Institution needs to emphasize new things and creating new challenges; hitting stretch targets.

- It is recommended that strategic emphases should be, High trust, openness participation leading to human development. Process Consultation (Building the Helping Relationship) as depicted by Edgar H. Schein and his ten principles as the essence of Process Consultation should be emphasized regularly. It is recommended that always try to be careful, and stay in touch with the current reality. It is recommended that Deming's Circle (PDSA) Plan Do - Study - Act should be adopted. It is an iterative four - step problem-solving process typically used in Organization process improvement. The Institute of Administrative Management (IAM) should illustrate its maps clearly.

- Criteria of Success should be based on development of Human Resources, teamwork, employee commitment and concern for people. The Institution should define success on the basis of having the most unique and/or newest products; winning in the marketplaces and outpacing the competition. There should be IAM Success Model in place. These can be achieved by using Competitive Analysis; Porter's Five Forces which would impact on an organization's behavior in a competitive market.

- To implement the desired changes, according to their conduct a follow-up assessment using the same instrument to see the dynamism and to check the sustainability.

- Finally, regular evaluation of Organizational Culture on the Institution shall be conducted in order to keep abreast of the strategic changes in the Organizational performance, as well as in the economy, is recommended.

\section{References}

i. Cameron, Kim S. and Quinn, Robert E. (1999) Diagnosing and Changing Organizational Culture New York: Addison-Wesley. $1^{\text {st }}$ edition.

ii. Dahama Op and OP Bhatnager Op.(1997). Education and Communication for Development, secondedition. Konark Publishers, New Delhi. 5th edition.

iii. Fekete, S., Keith, L. (2001), Companies are People, Too: Discover, Develop, and Grow Your Company's Personality. New York: Wiley.

iv. Francesco Marie Anne, Barry Allen Gold (2001). International organizational behavior second edition. Sage publications

v. Gareth Morgan. (1997). Images of organization. Thousand oaks. 1st edition: Sage publications.

vi. Hofstede Geert, (1991). Cultures and Organizations; Mcgraw- hill New York- $2^{\text {nd }}$ edition.

vii. Joanne Martin. (2002). Organizational culture-mapping the terrain; Sage publications printed in

viii. Lesikar. (1999). Busic Business Communication, fifth edition Homewood, Boston.

ix. Louis, M. (1983), Organizations as Culture-bearing Milieux, in Pondy L.R., Frost, P.M., Morgan,

x. luthans Fred. (2008). Organizational behavior; mcgraw- hill international- Singapore. Eleventh edition.

xi. Martin.J. (1995). The Great Transition: using the seven disciplines of Enterprise Engineering to Align people. Amacom.

xii. Martin, J., Siehl C. (1983), Organizational Culture and Counter-Culture: An Uneasy Symbiosis. Organizational Dynamics, 12(2): 52-64.

xiii. Miner B. John. (2007). Organizational Behavior; prentice- hill, private limited New Delhi

110001.

xiv. Penny Dick and Steve Ellis (1998). Introduction to organizational culture-third edition

xv. Quinn, Cameron and Rohrbaugh, John (1983), A spatial model of effectiveness criteria: Towards values approach to organizational analysis. Management Science, 29(3): 336-377. 04.09

xvi. Schueider, Benjamin, (1990). Organizational Climate and Culture, San Fransisco, Jessery.

xvii. Senge Peter, (1997). The Arts and practice of the learning organization Sage publications. $1^{\text {st }}$

xviii. Schein H. Edgar (1997), organizational culture and leadership- Jossey Bass- Publisher 1997 USA.

xix. Schein Edgar (1993). Organization culture and leadership in classics of organizations theory.

xx. Senge Peter, (1997). The Arts and practice of the learning organization Sage publications. $-1^{\text {st }}$ edition

xxi. The Measurement of Organizational Effectiveness: A Review of Relevant Research and Personnel Research and Development Center, Personnel Decisions. 